\title{
Mercy for money: Torture's link to profit in Sri Lanka, a retrospective review
}

\author{
Wendell Block, M.D., Jessica Lee M.D., ${ }^{*}$ Kera Vijayasingham B.A.*
}

\section{Key points of interest:}

- This paper supplements earlier studies on prevalence of bribe payments to end torture in Sri Lanka, adding trends throughout the war, after the war, involving multiple armed organizations, and across wide geographic locations.

- Victims may not genuinely be considered to be a security risk but are used for extortion.

- Significant economic and social impact on families is likely.

- Torture unlikely to stop until financial incentives are removed.

- High prevalence suggests that perpetrators act in collusion with their superiors and benefit from impunity.

\section{Abstract}

Background: The purpose of this retrospective study is to describe the pattern of bribe taking in exchange for release from torture, during and after the decades-long war in Sri Lanka. Methods: We reviewed the charts of 98 refugee claimants from Sri Lanka referred to the Canadian Centre for Victims of Torture for medical assessments prior to their refugee hearings in Toronto

*) Canadian Centre for Victims of Torture between 1989 and 2013. We tallied the number of incidents in which claimants described paying cash or jewelry to end torture, and collected other associated data such as demographics, organizations of the perpetrators, locations, and, if available, amounts paid. We included torture perpetrated by both governmental and nongovernmental militant groups. Collected data was coded and evaluated. Findings: We found that 78 of the 95 subjects $(82.1 \%)$ whose reported ordeals met the United Nations Convention Against Torture/International Criminal Court definitions of torture described paying to end torture at least once. 43 subjects paid to end torture more than once. Multiple groups (governmental and non-governmental) practiced torture and extorted money by doing so. A middleman was described in 32 percent of the incidents. Payment amounts as reported were high compared to average Sri Lankan annual incomes. The practice of torture and related monetary extortion was still reported after the end of the war, inclusive of 2013. Interpretation: Torture in Sri Lanka is unlikely to end while profit motives remain unchallenged. As well as health injuries, victims of torture and their families suffer significant economic injuries while their assailants are enriched. The frequent link between torture and impunity means multiple populations the world over are vulnerable to this abuse. 
Keywords: Sri Lanka, torture, bribe, extortion, retrospective chart review

\section{Introduction}

Reports of bribe payments to end torture are commonplace, yet the phenomenon is rarely given detailed attention. Torture's efficacy as a tool to increase security, and the related legal and ethical problems, are frequent subjects for public discussion. Medical accounts generally focus on the physical and psychological impacts torture has on affected individuals, rather than on torture's profound social sequelae. ${ }^{1}$ The purpose of this retrospective study is to illuminate one of torture's socio-economic dimensions within a particular context: the link between torture and bribe extortion during the 1983-2009 war in Sri Lanka, and during the war's immediate aftermath (2009-2013). Based on the reports of 98 Sri Lankan refugee claimants assessed in Canada during that time, this study identifies organizations whose members gained financially through torture, the amounts of cash involved, and the frequency with which detainees were released because they paid bribes. The political/security aims of the perpetrators, as reported by the victims as the overt motivation for their torture, distinguish these actions from the criminal form of kidnapping for ransom, which in itself is not considered torture.

By reporting descriptions of recurring patterns involving torture-ending bribes, it can be argued that financial extortion is intertwined with torture in Sri Lanka and that the profit motive is thus a potent driver of the practice of torture.

\section{Background}

Civil conflicts, and the locations in which these conflicts devolve into open violence, involve multiple histories, causes and consequences. Outsiders such as ourselves will inevitably omit or misrepresent what are important facts to many. In the following paragraphs, we give what is assuredly a very limited sketch of the context for this paper.

Four hundred years of colonial rule led to identification and administrative representation through essentialized ethnic categories. $^{2,3}$ (p3-39, p47-54) After Sri Lanka achieved independence from Britain in 1948, there was increasing friction between the Sinhalese majority and the Tamil minority. Government legislation and successive new constitutions promoted majority aspirations but eroded Tamil and other minority rights and their traditionally held protections.

A war for an independent Tamil state in the north and east of the island was eventually led by the Liberation Tigers of Tamil Eelam (LTTE, or Tamil Tigers). It began after years of political frustration and the development of several militant Tamil groups. Ultimately, open war broke out after the 1983 "Black July" riots in which one to three thousand Tamil citizens were killed in retaliation for the killings of Sinhalese soldiers in the north.

The LTTE developed their own sophisticated army and navy, and also used suicide and other bombings to attack their detractors and civilians to instill fear throughout the country. "Ethnic cleansing" of Sinhalese and Muslim people took place in Tamil "homelands". The LTTE also accepted and conscripted women as members of their fighting ranks, including the elite "Black Tigers" who carried out suicide attacks. This meant that young Tamil women, as well as men, would be suspected of being "terrorists". The LTTE were notorious for conscripting children and forcing them into their fighting ranks. ${ }^{4}$ For years the LTTE enforced their de facto governance over large regions under their control. 
For its part, the government was brutal in its response. The authorities were already empowered by emergency regulations, originally promulgated in 1971 under the Public Security Ordinances Act to facilitate suppression of the largely Sinhalese, classbased Janatha Vimukthi Peramuna (JVP) uprisings. The Prevention of Terrorism Act (PTA) of 1979, made permanent in 1982, had given the authorities further powers to arbitrarily detain terrorist suspects and move them to undisclosed locations. Millions of civilians were displaced by the war's violence and tens of thousands were killed. ${ }^{2}$ (p278) Detention and torture of civilians was common, as were disappearances. This did not change after Sri Lanka ratified the United Nations Convention against Torture in 1994. Also of note is that, in March of 2004, Sri Lanka ratified the United Nations Convention against Corruption.

Multiple Tamil paramilitary groups worked alongside the military in support of the government's aim to destroy the LTTE, and presumably to extend their own power and influence. In a major blow to LTTE hegemony in eastern Sri Lanka, "Colonel" Karuna and his fighters split from the LTTE in 2004 to form their own paramilitary group in support of the government. ${ }^{5}$ Government intelligence agencies, "home guards" and the police were all involved in the conflict.

Over the years of the war, there were a number of poorly observed ceasefires. The Indo-Sri Lanka Accord of 1987 brought the Indian Peace Keeping Force (IPKF) to the north and east of the island, until heavy losses inflicted by the Tigers forced their departure in 1990. Another important ceasefire was brokered by Norway and signed in 2002, but peace-talks failed and open conflict resumed in 2006. (6, p243)

The war between the Sri Lankan government and the LTTE was declared officially over in May of 2009. A long military campaign had pushed the LTTE out of their strongholds and cornered them on the east coast, where they were either killed or taken into detention. Velupillai Prabakharan, the supreme leader of the LTTE, was killed in the fighting, along with many other top leaders. Thousands of Tamil civilians had been coerced by both sides to retreat with the LTTE - as many as 40,000 civilians were killed in the final conflict and thousands were detained in "rehabilitation camps". ${ }^{7}$ (p32) In spite of the war's end, military suppression and abuses of human rights are ongoing in traditionally Tamil regions of the country. Detentions and torture continue to be reported by Sri Lankans. ${ }^{8}$

\section{Methodology}

The reviewed charts were those of all 100 Sri Lankan refugee claimants assessed by two family physicians from 1990 through December 2013. 89 of these medical examinations were originally conducted by Dr. Wendell Block, one of the authors of this article. The medical assessments consisted of relevant history-taking, careful examination of any scars or injuries attributed to torture, a detailed description of the physical findings in the medicolegal report along with a statement as to whether the findings were consistent with the given history. The claimants had been referred to the Canadian Centre for Victims of Torture (CCVT) by their immigration lawyers for medical documentation prior to their refugee hearings, where these medical reports were accepted as evidence by government immigration adjudicators.

The charts reviewed for this study included the claimant's legal narrative and the medical report. Two claimant files were excluded because they did not contain both of these documents $(n=98)$. For each 
individual, while reviewing their chart, a separate document was created to note their demographic data (including ethnicity, gender, year of birth, education level, occupation, marital status, year assessed by physician at CCVT) and the details of each reported incident of torture (including year of incident, age of individual during incident, military group involved, characteristics of detention, detention time, mediating group (if applicable), location of incident, judiciary involvement (if applicable), round-up versus individual detention, and related scars).

Using a predetermined coding system, the individual data was transferred onto a spreadsheet for grouping of information and comparison. In order to assess inter-rater reliability, each reviewer randomly selected ten of the other's charts and recollected the data. The data recorded the second time was consistent with the initial collection.

In February and March of 2014, the keywords "Sri Lanka civil war", "Sri Lanka human rights", and "Sri Lanka bribery" were used in a search of the University of Toronto Library's articles and databases (which include medical and interdisciplinary databases), looking for writing directly linking human rights abuses with bribe extortion. We also accessed the resources of organizations known to monitor human rights issues in Sri Lanka. Information about Sri Lankan incomes was readily accessed through Sri Lankan government websites.

Relevant reports included Transparency International's "In Pursuit of 'Absolute Integrity'-Identifying Causes for Police Corruption in Sri Lanka”, which addressed the issue of ongoing police corruption. ${ }^{9}$ "Police Torture Cases: Sri Lanka 19982011", an Asian Human Rights Commission publication, summarized the most serious 323 out of 1500 reports of torture during that time. ${ }^{10}$ The victims in these cases were not refugee claimants. A common theme was the police use of torture to gain confessions of crimes and/or to extort bribes from randomly arrested individuals, usually from the poorer classes.

The definition of torture used in this article is that of the United Nations Convention Against Torture, as well as Article 7 of the Rome Statute of the International Criminal Court (to include torture perpetrated by non-State combatant groups). ${ }^{11,12}$ These are broad definitions, and to form a clearer picture of the kinds of torture represented by this study's findings, an initial distinction is made between three subtypes: subtype (1) "classical" torture, in which the victim alleges physical and/or sexual abuse while detained at least overnight in a facility controlled by the perpetrator's organization; subtype (2) arbitrary detention, in which the victim alleges detention in poor conditions, without legal access, without knowledge of when they might be released, and with full knowledge that they could be physically/ sexually assaulted; 5 and, subtype (3) the victim alleges physical abuse without detention (at least not overnight).

\section{Findings}

The 98 subjects described 201 distinct detentions which included physical torture (first subtype). For 121 of these detentions $(60.2 \%)$, a clearly described payment gained the person's release. Incidents in which a release was arranged without the explicit description of payments of cash or jewelry were not counted. There were 20 clear descriptions of payments paid to end detentions which did not include overt physical abuse (second subtype). Payments were also made five times to end assaults by government authorities or militants outside of detention (third subtype). Thus, there were 146 torture-ending "bribe incidents". 
Table 1: Study Population Characteristics

\begin{tabular}{|c|c|}
\hline Characteristic & Total $(n)=98$ \\
\hline Ethnicity & $\begin{array}{l}\text { Tamil = } 89(90.8 \%) \\
\text { Sinhalese }=7(7.1 \%) \\
\text { Muslim =1 }(1 \%) \\
\text { Unspecified }=1(1 \%)\end{array}$ \\
\hline Gender & $\begin{array}{l}\text { Male }=90(91.8 \%) \\
\text { Female }=8(8.2 \%)\end{array}$ \\
\hline Year of birth & $\begin{array}{l}\text { Before } 1930=2(2 \%) \\
1930-1939=2(2 \%) \\
1940-1949=2(2 \%) \\
1950-1959=16(16.3 \%) \\
1960-1969=20(20.4 \%) \\
1970-1979=43(43.8 \%) \\
1980-1989=13(13.3 \%) \\
1990 \text { and after }=0\end{array}$ \\
\hline Education & $\begin{array}{l}\text { Primary }=6(6.1 \%) \\
\text { Secondary }=59(60.2 \%) \\
\text { Post-secondary }=18 \\
(18.4 \%) \\
\text { Unknown }=15(15.3 \%)\end{array}$ \\
\hline Occupation & $\begin{array}{l}\text { Fishers, farmers, labourers } \\
=44(44.9 \%) \\
\text { Commercial business } \\
=23(23.5 \%) \\
\text { Professionals = } 10(10.2 \%) \\
\text { Students }=4(4.1 \%) \\
\text { Unemployed }=2(2 \%) \\
\text { Unknown }=15(15.3 \%)\end{array}$ \\
\hline Marital status & $\begin{array}{l}\text { Married }=38(38.8 \%) \\
\text { Single }=24(24.5 \%) \\
\text { Widowed }=3(3.1 \%) \\
\text { Unknown }=33(33.7 \%)\end{array}$ \\
\hline $\begin{array}{l}\text { Time of medical } \\
\text { assessment in } \\
\text { Canada }^{\star}\end{array}$ & $\begin{array}{l}1989-2001=59(60.2 \%) \\
2002-2005^{\star \star}=11(11.2 \%) \\
2006-2009=6(6.1 \%) \\
2010-2013^{\star \star \star}=22 \\
(22.4 \%)\end{array}$ \\
\hline
\end{tabular}

* In all cases, a significant amount of time had elapsed between the alleged incidents of torture and the time of medical examination

** Ceasefire period in Sri Lanka

$\star \star \star$ War was officially over
Three of the 98 individuals made their Canadian refugee claims for reasons unrelated to torture. Of the 95 who had been tortured, $73(76.8 \%)$ described at least one incident in which they paid to end a detention during which physical torture took place. Another five described paying at least once to end a detention not involving physical abuse, or to end an assault outside of detention, in circumstances believed to satisfy the UN torture definition. Thus, of the 95 individuals with a history of torture, $78(82.1 \%)$ described paying to end it at least once. $43(55.1 \%)$ reported paying to end more than one ordeal.

Table 2: Number of incidents ${ }^{\star}$ per claimant

\begin{tabular}{cc}
\hline $\begin{array}{c}\text { Number of } \\
\text { incidents }\end{array}$ & $\begin{array}{c}\text { Number of claim- } \\
\text { ants thus affected }\end{array}$ \\
\hline 0 & 17 \\
1 & 35 \\
2 & 28 \\
3 & 9 \\
4 & 4 \\
5 & 1 \\
6 & 0 \\
7 & 1 \\
\hline${ }^{*}$ Incident $=$ an incident of paying to end torture
\end{tabular}

The 146 bribe incidents could be characterized in more detail as follows:

Timing: Two incidents occurred in 19841985. 17 incidents took place in the period 1987-1990, when the Indian Peace Keeping Force (IPKF) was in northern Sri Lanka. 105 incidents took place from 1991-2002, seven during the 2002-2007 ceasefire, and three between 2007 and the war's end in mid2009. 12 incidents occurred after the war. 
Table 3: Military/Militant groups involved in incidents *

\begin{tabular}{ccc}
\hline Group & $\begin{array}{c}\text { Number of } \\
\text { incidents }\end{array}$ & $\begin{array}{c}\text { Years } \\
\text { incidents } \\
\text { occurred }\end{array}$ \\
\hline SL Military & 60 & $1984-2013$ \\
Police & 47 & $1992-2008$ \\
LTTE & 14 & $1990-2003$ \\
Paramilitary & 13 & $1989-2011$ \\
groups & & $2009-2010$ \\
CID & 3 & 1989 \\
IPKF & 6 & - \\
Others & 3 & \\
\hline
\end{tabular}

*Incident = an incident of paying to end torture/ detention

Paramilitary groups $=E P D P, P L O T E, E P R L F$ and Karuna

LTTE $=$ Liberation Tigers of Tamil Eelam $C I D=$ Criminal Investigation Department $I P K F=$ Indian Peacekeeping Force

Offenders: See Table 3.

Bribe mediators: In 47 incidents, a specific individual or group was named as a third party who arranged the bribe payment (family members not included). The mediators were described as "brokers" in five cases. Lodge owners in Colombo (Sri Lanka's capital) were described as performing this service in 11 cases. Providers of temporary housing to Tamils fleeing the conflict zones en route to leaving the country, these lodge owners would step in with a payment when the police conducted Tamil round-ups (round-ups which led to detention and torture, generally for a few days). Other mediators included Tamil paramilitary groups (7 cases), "a Muslim man" (6 cases - one of these was "a Muslim woman"), and the agents who had been hired to get the subject out of Sri Lanka (8 cases). Other descriptors were "a lawyer", "the Catholic priest", the "Gram Sevaka" (village leader), "someone with connections", and "a friend of my father's". In one case a bribe was paid directly to a nurse at a hospital to enable an escape. One man, who in 1996 had been apprehended by the army and turned over to the police in Vavuniya, gave this description of his broker: he was "one of the middleman (sic) who arranged for and collected bribes on behalf of the army".

Bribe amounts: A numeric amount was recorded in 73 incidents. Jewelry was used in five incidents. The bribe amount was not recorded for 68 incidents. Table 4 shows the lowest, highest and median amounts reported per phase of the war.

Detention times: Time in detention was reported as one month or less in 112 of 141 detentions ended by a bribe $(79.4 \%)$. The longest detention ended by a bribe was 2.5 years.

Torture method: Although the aims of this study did not include a quantitative catalogue of the methods of torture described by the subjects, the methods should be mentioned. The most common physical torture method included blunt beatings with slaps, punches, kicks, and blows with implements such as batons, sand-filled pipes and rifle butts. Other torture methods included sexual assault, asphyxiation, suspension, burns, and stress positions. Psychological techniques included isolation, humiliation, threats (including death threats), exposure to the torture of others, sleep interruption, and verbal abuse. Detainees were confined in dirty, cramped quarters without beds, toilets, or ready access to water. Food was of poor quality and minimal. There was no access to legal assistance or communication with the 
Table 4: Amounts paid per phase of war, in Sri Lankan Rupees (Rs. 100,000 equals 746 USD (Fune 4, 2015))

\begin{tabular}{|c|c|c|c|c|c|}
\hline Phase of War* & Period & $\begin{array}{l}\text { Lowest } \\
\text { amount } \\
\text { reported }\end{array}$ & $\begin{array}{l}\text { Highest } \\
\text { amount } \\
\text { reported }\end{array}$ & Median & $\begin{array}{l}\text { No. of } \\
\text { incidents with } \\
\text { amount } \\
\text { reported/Total } \\
\text { no. of bribe } \\
\text { incidents }\end{array}$ \\
\hline Eelam War I & 1983-1986 & 20,000 & 20,000 & 20,000 & $1 / 2$ \\
\hline IPKF presence & 1987-1989 & 15,000 & 25,000 & 25,000 & $5 / 14$ \\
\hline Eelam War II & 1990-1994 & 3,000 & 300,000 & 29,000 & $11 / 16$ \\
\hline Eelam War III & 1995-2001 & 5,000 & 300,000 & 37,500 & $39 / 92$ \\
\hline $\begin{array}{c}\text { Norway } \\
\text { brokered } \\
\text { Ceasefire Agree- } \\
\text { ment (CFA) }\end{array}$ & $2002-2003$ & 50,000 & 500,000 & 275,000 & $2 / 2$ \\
\hline $\begin{array}{l}\text { LTTE/Karuna } \\
\text { split and } \\
\text { Tsunami (CFA } \\
\text { still in effect) }\end{array}$ & 2004-2005 & 80,000 & 120,000 & 100,000 & $3 / 4$ \\
\hline Eelam War IV & $\begin{array}{l}\text { 2006- Jun } \\
2009\end{array}$ & 100,000 & 300,000 & 200,000 & $2 / 4$ \\
\hline Post War & Jul 2009-2013 & 25,000 & $2,500,000$ & 225,000 & $10 / 12$ \\
\hline
\end{tabular}

*Phases of War as described in The Cage 6 (Timeline p240-244)

outside, and no sense of how long each detention would last.

Location: The incident location was provided in 137 cases. See Figure 1.

Round-ups: In 48 incidents, the reported detention began with a group round-up.

Legal involvement: Access to a lawyer was described in one case.

Associated physical scars: Most of the study subjects reported being tortured multiple times. Of the 78 individuals who had paid at least once to end torture, 76 had physical scars consistent with at least one episode of torture. Documentation of scarring and on-going injuries related to torture was the predominant reason for referral to the two assessing doctors in the first place. 43 of the 146 bribe incidents resulted in scars still apparent at the medical assessment.

Age at time of incident: Most incidents (120) occurred when people were age 21 to 50 , but 22 were under the age of 21 (three were 15 or younger). The two eldest were 68 and 71 .

Women: Five of the eight women (all Tamil) described paying to end torture, one of them twice. Two paid with jewelry.

Sinhalese men: Four of the seven Sinhalese men described paying bribes to end torture: 
Figure 1: Map showing incident locations, year of incidents and perpetrators

1984,1985 .

$1989,1989,1989$,

$1989,1989,1989$

1990,1990,

1993,1993,1995,1995,

1996,1996,1996,1996,

$1997,1997,1997$.

$1998,1998,1998,1998,1999$

$1999,1999,2000,2000,2000$

2001,2001,2001,2003,2006,

$2011,2011,2012$

\begin{tabular}{|l|}
\hline SLA \\
Police \\
CID \\
IPKF \\
LTTE \\
\hline PARAMILITARY \\
\hline
\end{tabular}

$1990,1992,1992,1993,1994$, $1994,1993,1993,1995,1995$, $1995,1995,1995,1995,1995$, $1995,1995,1995,1996,1996$, $1996,1996,1996,1996,1996$, $1997,1997,1997,1998,1998$, $1998,1998,1998,1998,1998$, $1998,1999,1999,1999,1999$, $1999,1999,2000,2000,2000$, 2001,2001,2004,2004,2004, $2005,2008,2010$

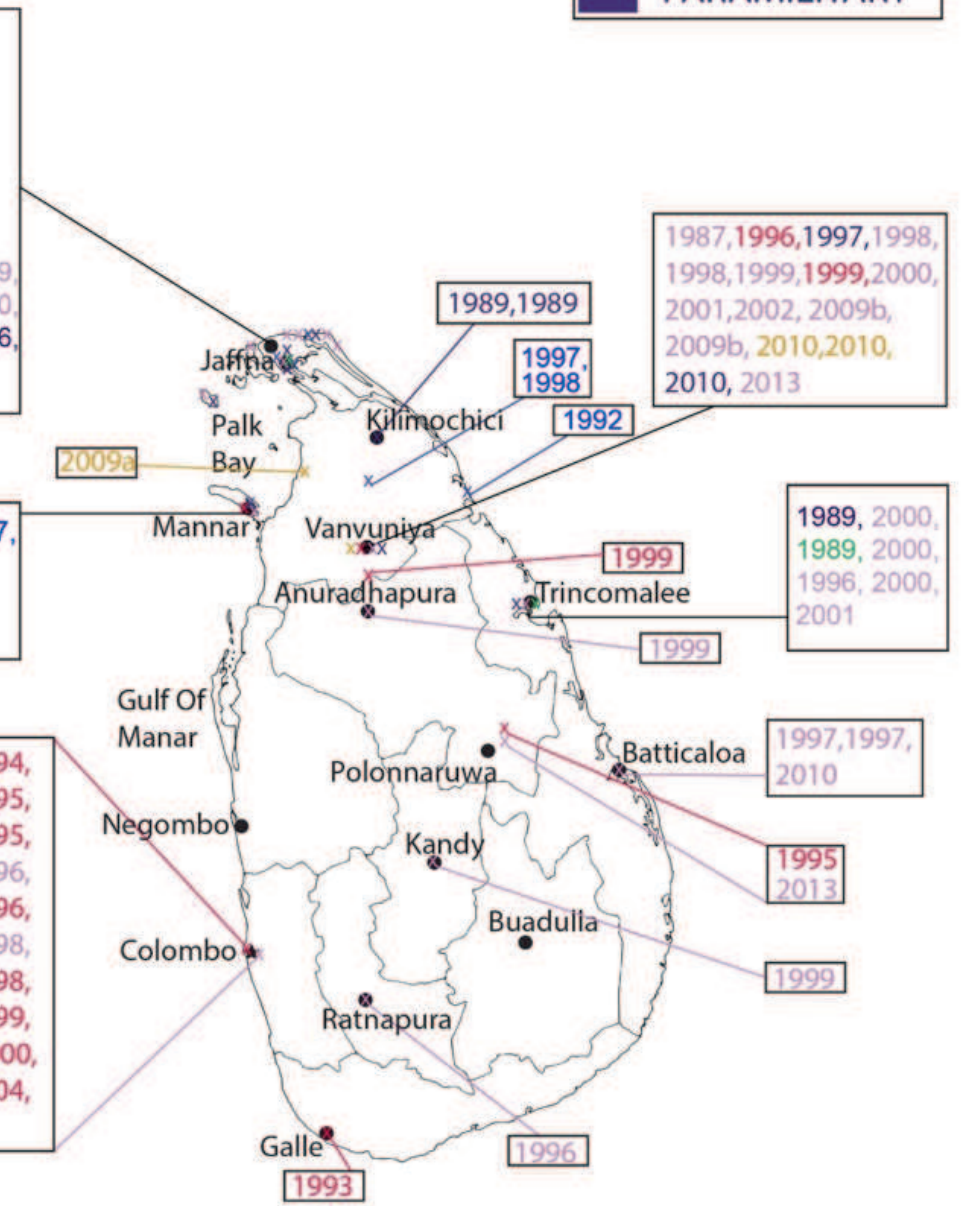


three to policemen, and one to army personnel.

Reasons given for torture: In their legal narratives and medical histories, the study subjects generally related the accusations leveled by their torturers. When LTTE were the torturers, the reasons for torture included refusal to cooperate with them, and suspicion of giving information to the army (or IPKF). In the majority of cases, those tortured by the military, police, or paramilitaries were accused of being LTTE members, of supporting LTTE, or of having information about LTTE. There was an implied assumption that to be Tamil was to be a suspected terrorist. "Round-ups" of Tamils occurred in the conflict zones after LTTE actions, and also in Colombo where Tamils from outside the city were suspect. One person was accused of supporting the JVP. Paramilitaries also used torture to pressure their victims into joining them. Demands for money were generally not overt at the beginning, though one person recorded that the "EPDP demanded 2 lakhs [200,000 Rs.] from me, otherwise they would turn me over to the police ... I did not have that kind of money. The EPDP took me to the Wellawatte police station and I was kept there." After the war's end, Tamil victims continued to be accused of being members of, supporting, or trying to reorganize LTTE.

\section{No mention of paying bribes to end} torture: The 17 individuals who did not mention any bribe payments to end at least one of their episodes of torture were quite similar to the study group as a whole. Nine of these individuals reported making payments to LTTE to avert a threat.

Other extortions: 77 of the 98 people described at least one clear incident of extortion outside the context of torture generally by LTTE ( 68 of the 77 ). These extortions were carried out with threats to assault, kill, or detain the victims; or to conscript their children. 15 people described these extortions by Tamil paramilitary groups, four by the IPKF, four by the police, and eight by the military. The threats were not always demands for cash. People were also forced to give the products of their work, their vehicles and belongings, their labour, and even their blood (for transfusions).

\section{Discussion}

Amnesty International's "Locked Away—Sri Lanka's Security Detainees” describes reports of police and military personnel demanding bribes for the release of security detainees. ${ }^{13}$ Freedom from Torture's "Tainted Peace: Torture in Sri Lanka since May 2009", based on the medicolegal assessments of 148 people who had been tortured by the Sri Lankan authorities between May 2009 and September 2013, reports that $105(71 \%)$ gained their release by paying bribes. ${ }^{14}$ (p9) In 2014, the Bar Human Rights Committee of England and Wales, along with the International Truth and Justice Project of Sri Lanka, published their STOP study entitled "Torture and Sexual Violence in Sri Lanka 2009-2014". This study presents the results of structured interviews with Sri Lankan torture survivors, conducted by nine independent lawyers; in 38 of the 40 cases, the survivor reported that a bribe had been paid to gain their release. ${ }^{15}$ The same group's follow-up study of 20 Tamils who had been tortured in 2015 showed that the practice continues: 19 of the 20 reported that ransoms had been paid to gain their release, and the bribe amounts were high (bribes ranged from 350,000 to 1,000,000 Rs.). In "The Rule of Law in Decline - Study on Prevalence, Determi- 
nants and Causes of Torture and Other Forms of Cruel, Inhuman or Degrading Treatment or Punishment in Sri Lanka", Kishali Pinto-Jayawardena analyzes the lack of protection from torture afforded to Sri Lankan citizens, in spite of Sri Lanka's international agreements, domestic legislation and institutions which in law should provide them with such protection. ${ }^{16}$

While these studies note frequent bribe payments to end torture, the present study examines the phenomenon in more detail; throughout the war, including ceasefires and the post-war period, and across widespread geographic locations. The practice was not limited to any particular organization, but was practiced by government officials and non-government militants alike. Although most victims were young adults, individuals across all ages and in multiple social groups were targeted - their chief commonality was the accusation that they supported the enemy. The high prevalence of release by payment suggests that the victims were not truly considered to be a high risk to security. Further, the high prevalence also suggests that the practice could only have taken place as a result of the offending authorities/ militants acting in collusion with their superiors.

The descriptions of bribe payments within the documents did not describe the processes by which these transactions were initiated or negotiated, aside from the mention of mediators. However, even if payment initiation was on the side of the victim, in a context in which these transactions are common and the discrepancy in power between the parties being so great, responsibility must lie with the torture perpetrators.

Does the "profit motive" act as a primary motive for the apprehension, detention and torture of individuals conveniently labeled as "terrorists" or "enemy supporters"? Economists assume that people tend to pursue opportunities to better their lot in life, while minimizing risk. ${ }^{17}$ Thus individuals or groups who are given the opportunity to profit through torture are likely to do so, if on balance the benefits outweigh the potential risks.

Comparing the bribe amounts in Table 4 with national household incomes (Table 5) shows that, in Sri Lanka, the financial rewards gained through torture are high. It should be noted that the inflation rate in Colombo for this time period was $696 \%$, or roughly $30 \%$ per year (based on the Colombo Consumer Price Index (CPPI) as reported by the Sri Lanka Central Bank). ${ }^{18}$ Inflation rates would likely have been higher for regions of the country more directly affected by war. Further instructive comparators include: a police constable's monthly wage in 2004 was Rs. 9,605 to $14,225,{ }^{19}$ while the 2013 Sri Lankan military website advertised monthly gross pay for officer cadets as Rs. $26,617 .{ }^{20}$

Table 5: Sri Lankan Household Incomes ${ }^{19}$

\begin{tabular}{cc}
\hline Year & $\begin{array}{c}\text { Median Monthly Sri } \\
\text { Lankan Household } \\
\text { Income (Rs) }\end{array}$ \\
\hline $1990 / 91$ & 2,547 \\
$1995 / 96$ & 3,793 \\
2002 & 8,387 \\
$2009 / 2010$ & 23,746 \\
$2012 / 2013$ & 30,814 \\
\hline
\end{tabular}

At the same time as financial rewards gained through torture being high, a review of Sri Lanka's political context reveals that the risks to perpetrators are very low. The Prevention of Terrorism Act and related security measures allow authorities to detain "sus- 
pects" without charge, in undisclosed locations, and for extended periods of time. The state of impunity for government agencies, and the paramilitary groups they protect, is well documented. According to the International Jurists Commission, as of 2012, there had been only five court convictions of authorities charged with torture. In one case, the Officer-in-Charge at the Polpithigama Police Station was found guilty of torturing a seven year old. The Kurunegala High Court sentenced the accused to two years in prison (the mandatory minimum sentence is seven years) and ordered the accused to pay the victim Rs. 25,000. ${ }^{21}$ (Sri Lanka's 1994 Convention against Torture Act legislates fines should be between Rs. 10,000 and Rs. 50,000 - an amount unchanged during the high inflation time period of this study, and another useful comparator to bribe amounts reported). ${ }^{22}$

Sri Lanka is a signatory to the UN Convention against Corruption, and has an established Commission to Investigate Allegations of Bribery or Corruption. ${ }^{23}$ However, the Commission is unable to proactively initiate investigations of its own, and has been the subject of political interference. $^{24}$

As for LTTE, they operated in large regions for many years without accountability and were free to "tax" and extort resources in any way they chose, ${ }^{4,25}$ with the only apparently negative consequence being the loss of "hearts and minds". Some subjects in the current study reported closing their businesses, or reducing their farming/fishing production, because positive output simply brought higher demands from LTTE.

In terms of impact on victims, it is possible that many would not have been apprehended at all without the profit motive. Torturers possibly employ harsher methods to heighten family fears and thereby increase the amounts they can extort. The desperation of the victims' families is apparent in the large sums they were willing to pay to gain the victims' release. The large amounts paid also suggest that the economic impact of paying them would have been severe; a family's ability to pay likely depended on the liquidation of assets, loans arranged under duress, or the resources of extended family networks (including the diaspora). The consequences to those unable to pay the demanded bribes are not apparent to this study.

Furthermore, it is noteworthy that $55.1 \%$ of the study subjects paid bribes more than once to end torture. Study subjects paid further large amounts to leave the country (often describing hired agents, the payment of bribes at checkpoints, to police in Colombo, and to passport control), plus the cost of transport leading to Canada. These costs are over and above the 'usual' economic costs of torture, which include interrupted or lost employment/education, temporary or permanent disability, and family/social disruption. ${ }^{26}$ (p40-69) Far-reaching consequences would therefore have to be borne by subject's families with respect to their economy, quality of life, and ultimately health, in addition to suffering from the multiple effects of a protracted war.

On a societal level, it is well known that torture and the fear of torture is successful in intimidating and silencing opposition. ${ }^{26,27}$ The threat of torture - to oneself or to loved ones - changes behavior through fear of pain, rape, permanent injury, and disappearance or execution. Given this study's findings, in a context where torture routinely brings the extortion of large sums of cash, it is likely that intimidation through torture also functions by instilling a fear of severe economic injury to a family, business or career. 


\section{Limitations}

This study's data was collected retrospectively, from documents whose primary purpose was not an inquiry into bribes. This likely resulted in under-reporting of the relevant information.

Subjects may have exaggerated their reports of injustice to strengthen their application for refugee status, as the purpose of the medical assessments was to document physical and/or psychological torture for the claimant's refugee hearing. This could include their reports of the torture they experienced as well as their reports of bribe paying. The fact that the information was collected at an overseas setting eliminated any possibility of substantiating their reports through local secondary sources. Information identifying those refugee claims found "not credible" by the Canadian Immigration Review Board was not available at the time of the review. Although the subjects represent a broad range of educational and occupational backgrounds, the lack of direct information regarding their incomes is a serious limitation.

The findings of this study focus on the behavior of low-ranking officials. The impunity granted to them and to allied paramilitaries must serve the interests of those in power. These links are opaque to this study's methodology, but it would be an error to assume they do not exist.

Lastly, women are under-represented in this study. The female physician whose assessments contributed to this study was no longer available after 2001, and the male physician generally assessed male refugee claimants. It is particularly unfortunate that there are no female subjects to represent the final years of the war and its aftermath.

\section{Conclusions}

1) In a context where torture turns a profit, it is very unlikely that torture will be stopped until the financial incentives are removed.

2) Human rights organizations working with torture survivors should routinely collect specific data about bribe extortion (amount paid, to whom, impact). United Nations rapporteurs to the UN Commission for Human Rights should be required to investigate and report the use of torture to extract bribes. The States responsible should be held to account. The United Nations' 2015 Investigation on Sri Lanka, conducted by the Office of the High Commissioner for Human Rights regarding possible war crimes, does report bribe payments as a frequent means to release for "surrendees" held in detention (and often tortured) at the war's end. ${ }^{28}$ However, three earlier relevant UN Human Rights Commission reports reviewed are silent on this subject. 5, 8, 29 Neither the Sri Lankan government's 'Report of the Commission of Inquiry on Lessons Learnt and Reconciliation', nor the UN Human Rights Commissioner's formal response, address this abuse. ${ }^{30}$

3) In Torture and Impunity, Alfred McCoy argues that torture leads to empowerment of the torturer in terms of social authority. ${ }^{31}$ (p114-150) Goodhand et al., based on research done in war-affected Sri Lankan communities, describe shifts of social capital in the context of violence. ${ }^{32}$ Our study shows that torture also leads to financial empowerment of the torturer, and to economic weakening of the targeted individual/group. Post-conflict efforts to achieve civil reconciliation must address the particular ways in which "wealth" has forcibly been moved between community groups. 
4) The excesses revealed in this study provide another illustration of what happens when individuals/institutions have license to exert unlimited power over other human beings. Impunity and lack of accountability should not be seen as unique to Sri Lanka, and something which 'developed' countries eschew to ensure "ethical torture."; impunity generally accompanies government authorizations to use "coercive techniques", exemplified by the U.S. Administration making enormous efforts to ensure impunity for CIA and military personnel engaged in torture after $9 / 11 .^{31}$

\section{Ethics committee approval}

This study was approved by the Health Sciences Research Ethics Board (REB) at the University of Toronto under the REB's delegated review process.
References

1. Pedersen D. Political violence, ethnic conflict, and contemporary wars: broad implications for health and social well-being. Soc Sci Med. 2002 Jul; 55(2):175-190.

2. Wickramasinghe N. Sri Lanka in the Modern Age: A History. London: Hurst; 2014.

3. Somasundaram D. Scarred Communities - Psychosocial Impact of Man-made and Natural Disasters on Sri Lankan Society. New Delhi: Sage Publications Pvt; 2014.

4. The LTTE, Child Soldiers and Serial Disasters: A Challenge Without an Answer [Internet]. Sri Lanka: The University Teachers for Human Rights (Jaffna) Sri Lanka Information Bulletin No. 27; 2001 [cited 2016 July 10]. Available from: http:// www.columbia.edu/itc/sipa/U4759x01/client_ edit/27a.pdf

5. Nowak M. Promotion and protection of all human rights, civil, political, economic, social and cultural rights, including the right to development: Report of the Special Rapporteur on torture and other cruel, inhuman or degrading treatment or punishment - Mission to Sri Lanka (A/HRC/13/39) [Internet]. Geneva: United Nations; 2008 [cited 2015 March 1]. Available from: http://www2.ohchr. org/english/bodies/hrcouncil/docs/13session/AHRC-13-39.pdf

6. Weiss G. The Cage: the Fight for Sri Lanka and the Last Days of the Tamil Tigers. New York: Bellevue Literary; 2012.

7. Sri Lanka 2013 Human Rights Report [Internet]. [Place unknown]: U.S. Department of State; 2013 [cited 2014 Apr 24]. Available from: http://www. state.gov/documents/organization/220616.pdf

8. Concluding observations on the fifth periodic report of Sri Lanka (CCPR/C/LKA/CO/5) [Internet]. [Place unknown]: UN Human Rights Committee; 2014 [cited 2015 March 26]. Available from: http://tbinternet.ohchr. org/_layouts/treatybodyexternal/TBSearch. aspx? TreatyID $=8 \&$ Doc TypeID $=5$

9. In Pursuit of "Absolute Integrity"-Identifying Causes for Police Corruption in Sri Lanka [Internet]. Colombo: Transparency International Sri Lanka; 2006 [cited 2015 Apr 3]. Available from: http://www.tisrilanka.org/pub/pb/pdf/TISL $\% 20$ Police\%20Project\%20-\%20English.pdf

10. Police Torture Cases, Sri Lanka 1998-2011 [Internet]. Hong Kong: Asian Human Rights Commission; 2011 [cited 2015 Apr 5]. Available from: http://www.humanrights.asia/resources/specialreports/AHRC-SPR-001-2011

11. Convention against Torture and Other Cruel, Inhuman or Degrading Treatment or Punishment 
[Internet]. [Place unknown]: OHCHR; 1984 [cited 2015 Mar 1]. Available from: http://www. ohchr.org/EN/ProfessionalInterest/Pages/CAT.aspx

12. Article 7, Rome Statute of the International Criminal Court [Internet]. [Rome]: United Nations; 1998 [cited $2017 \mathrm{Feb} 2$ ]. Available from: http:// legal.un.org/icc/statute/99_corr/cstatute.htm

13. Locked Away: Sri Lanka's Security Detainees [Internet]. London: Amnesty International; 2012 [cited 2014 April 12]. Available from: http://files. amnesty.org/archives/asa370032012eng.pdf

14. Tainted Peace: Torture in Sri Lanka since May 2009 [Internet]. [Place unknown]: Freedom from Torture; 2015 [cited 2015 Mar 22]. Available from: http://www.refworld.org/pdfid/55cdacab4. pdf

15. Sooka Y. STOP Report: An Unfinished War - Torture and Sexual Violence in Sri Lanka 2009-2014. The Bar Human Rights Committee of England and Wales (BHRC) and The International Truth and Justice Project; 2014.

16. Pinto-Jayawardena K. The Rule of Law in Decline: Study on Prevalence, Determinants and Causes of Torture and Other Forms of Cruel, Inhuman or Degrading Treatment or Punishment in Sri Lanka. Copenhagen: The Rehabilitation and Research Centre for Torture Victims; 2009.

17. Block, Wendell. Message to: Janet Currie, Henry Putman Professor of Economic and Policy Affairs, Princeton University. 2015 January 7. [3 paragraphs].

18. Central Bank of Sri Lanka - Annual Report 2013: Special Statistical Appendix - Trends in Key Economic Variables [Internet]. Colombo: Central Bank of Sri Lanka; 2013 [cited 2015 Feb 27]. Available from: http://www.cbsl.gov.lk/pics_n_ docs/10_pub/_docs/efr/annual_report/AR2013/ English/content.htm

19. Household Income and Expenditure Survey - 2012-2013, Final Report [Internet]. Battaramulla: Department of Census and Statistics Sri Lanka; 2015 [cited 2015 Mar 1]. Available from: http://www.statistics.gov.lk/HIES/ HIES2012_13FinalReport.pdf

20. Sri Lanka Army [Internet]. [Place unknown]: Sri Lanka Army [cited 2015 Jan 15]. Available from: www.army.lk/PayAndOtherEnglish.php

21. Authority without Accountability: The Crisis of Impunity in Sri Lanka [Internet]. Geneva: International Commission of Jurists; 2012 [cited 2015 March 26]. Available from: http://dx.doi. org/10.1163/2210-7975_hrd-0088-0335

22. Convention against Torture and other Cruel, In- human or Degrading Treatment or Punishment Act (No.22) [Internet]. [Place unknown]: Human Rights Commission of Sri Lanka; 1994 [cited 2015 April 3]. Available from: http://www.hrcsl. 1k/PFF/LIbrary_Domestic_Laws/Legislations_related_to_Torture/Convention\%20against\%20Torture $\% 201994 \% 20$ of $\% 2022$.pdf

23. Commission to Investigate Allegations of Bribery or Corruption [Internet]. Colombo: Commission to Investigate Allegations of Bribery or Corruption; 2009 [cited $2015 \mathrm{Feb}$ 27]. Available from: http://www.ciaboc.gov.lk/web/ (The Sri Lankan "Bribery Act" is available at this website)

24. Sri Lanka 2014 Human Rights Report [Internet]. [Place unknown]: U.S. Department of State; 2014 [cited 2016 Mar 26]. Available from: http://www.state.gov/j/drl/rls/hrrpt/ humanrightsreport/\#wrapper

25. Funding the Final War: LTTE Intimidation and Extortion in the Tamil Diaspora [Internet]. United Kingdom: Human Rights Watch; 2006 [cited $2015 \mathrm{Feb}$ 19]. Available from: http://dx.doi. org/10.1163/2210-7975_hrd-2156-0527

26. Arcel LT et al, ed. Treatment of Torture and Trauma Survivors in a Post-war Society. Sarajevo: Association for Rehabilitation of Torture Victims, Centre for Torture Victims (CTV Sarajevo); 2003.

27. Quiroga J, Jaranson J. Politically-motivated torture and its survivors: A desk study review of the literature. Torture. 2005: 16(2-3): 30.

28. Report of the OHCHR Investigation on Sri Lanka (OISL), Advanced Version (A/HRC/30/CRP.2) [Internet]. [Place unknown]: UN Human Rights Council; Sep 2015 [cited 2015 Mar 23]. Available from: http://www.ohchr.org/EN/HRBodies/ HRC/RegularSessions/Session30/Documents/A. HRC.30.CRP.2_E.docx

29. Report of the United Nations Committee against Torture, Supplement No. 44 (A/67/44) [Internet]. [Place unknown]: United Nations; 2012 [cited 2015 March 26] Available from: http://www. un.org/documents/ga/docs/50/plenary/a50-44.htm.

30. Report of the Commission of Inquiry on Lessons Learnt and Reconciliation [Internet]. [Place unknown]: Ministry of Defence Sri Lanka; 2011 [cited 2016 March 26]. Available from: http:// www.defence.lk/warcrimes/lessons_learnt_and_reconciliation_commission_final_report.html

31. McCoy AW. Torture and Impunity - The U.S. Doctrine of Coercive Interrogation. Madison: $U$ of Wisconsin; 2012.

32. Goodhand J, Hulme D, Lewer N. Social Capital and the Political Economy of Violence: A Case Study of Sri Lanka. Disasters. 2000 Dec; 24(4):390-406. 